\title{
ENVIRONMENTAL IMPACT ASSESSMENT OF THE TERRITORIES IN THE VICINITY OF COMMISSIONING REGIONAL RADIOACTIVE WASTE MANAGEMENT FACILITY
}

Zozul YuN $\bowtie$, Kiselev SM, Laschenova TN, Shlygin W, Akhromeev SV, Gimadova TI, Malakhova AN, Shashkova OB, Oskina KYu

Burnasyan Federal Medical Biophysical Center, Moscow, Russia

The Regional center of conditioning and long-term storage of radioactive waste is being constructed in Primorsky Krai, where radioactive waste (RW) management concerns have been especially acute. The project involves intensification of activities related to RW management, as well as to building the new technology block for RW reprocessing, storage facility and boiler house. The study was aimed to perform environmental impact assessment of the territories in the vicinity of the Regional center of conditioning and long-term storage of radioactive waste prior to the facility commissioning. Radiation situation was assessed by radiometric and spectrometric methods; the levels of heavy metals were evaluated by atomic absorption spectrometry. Heavy metal (lead, nickel, copper, etc.) and arsenic levels exceeding or, in certain cases, similar to maximum permissible concentration (MPC) were found in soil and ground. Radiation situation is characterized by background levels of artificial radionuclides ${ }^{137} \mathrm{Cs}$ and ${ }^{90} \mathrm{Sr}$ in environmental media. Quality of water in wells and boreholes was largely compliant with the requirements established for groundwater used in decentralized water supply systems, with the exception of boreholes, in which the arsenic levels exceeding MPC were detected. The average annual public dose was $0.046 \mathrm{mSv}$ excluding natural regional background radiation, which was below the dose limit. Carcinogenic health risks induced by radiation and chemical factors was $4 \times 10^{-6}$ and $6 \times 10^{-6}$ respectively. The obtained results form the basis for setting reference values of environmental contamination prior to the Regional center of conditioning and long-term storage of radioactive waste commissioning and can be used for regulatory supervision during the facility operation.

Keywords: nuclear legacy site, radiological monitoring, carcinogenic risk, artificial radionuclides, heavy metals, public health, radiation situation

Author contribution: Zozul YuN - preparation and analysis of research data; Kiselev SM, Laschenova TN — overall management, analysis of research data; Shlygin W - assessment of radiological situation, data processing; Akhromeev SV — spectrometry, data acquisition; Gimadova TI — thermoluminescence dosimetry; Malakhova AN — data acquisition, working with TL-dosimeters; Shashkova OB — atomic absorption spectrometry; Oskina KYu — radiochemistry research.

Compliance with ethical standards: the study was carried out in full compliance with radiation safety measures and labour protection requirements. No research involving himan subjects or animals was performed.

$\checkmark$ Correspondence should be addressed: Yilia N. Zozul Zhivopisnaya, 46, 123098, Moscow; julnik@list.ru

Received: 15.07.2021 Accepted: 11.08.2021 Published online: 27.08.2021

DOI: $10.47183 /$ mes.2021.022

\section{КОМПЛЕКСНАЯ ГИГИЕНИЧЕСКАЯ ОЦЕНКА ТЕРРИТОРИЙ В РАЙОНЕ РАЗМЕЩЕНИЯ СТРОЯЩЕГОСЯ РЕГИОНАЛЬНОГО ЦЕНТРА ПО ОБРАЩЕНИЮ С РАДИОАКТИВНЫМИ ОТХОДАМИ}

Ю. Н. Зозуль $₫$, С. М. Киселев, Т. Н. Лащенова, В. В. Шлыгин, С. В. Ахромеев, Т. И. Гимадова, А. Н. Малахова, О. Б. Шашкова, К. Ю. Оськина

Федеральный медицинский биофизический центр имени А. И. Бурназяна, Москва, Россия

В Приморском крае, где вопросы обращения с радиоактивными отходами (РАО) стоят весьма остро, ведется строительство Регионального центра кондиционирования и долговременного хранения радиоактивных отходов (РЦКДХ). Проект предполагает интенсификацию работ по обращению с РАО, а также строительство нового технологического корпуса по переработке РАО, пункта хранения и котельной. Целью исследования было дать комплексную гигиеническую оценку территорий в районе расположения РЦКДХ перед вводом его в эксплуатацию. Оценку радиационных параметров выполняли с использованием методов радиометрии и спектрометрии, содержания тяжелых металлов - методом атомно-абсорбционной спектрометрии. В почвах и грунтах выявлено присутствие тяжелых металлов (свинец, никель, медь и др.) и мышьяка в концентрациях, превышающих фоновые значения и в ряде случаев предельно допустимую концентрацию (ПДК). Радиационную обстановку характеризуют фоновые значения активности техногенных радионуклидов ${ }^{137} \mathrm{Cs}$ и ${ }^{90} \mathrm{Sr}$ в объектах окружающей среды. Качество воды колодцев и скважин в основном соответствует требованиям для подземных вод, используемых для нецентрализованного водоснабжения, за исключением скважин, где присутствует мышьяк в концентрации выше ПДК. Среднегодовая интегральная доза облучения населения за вычетом естественного регионального фона составила 0,046 мЗв, что ниже предела дозы. Канцерогенный риск для здоровья населения от воздействия радиационного и химического фактора составил $4 \times 10^{-6}$ и $6 \times 10^{-6}$ соответственно. Полученные результать являются основой для установления референсных значений состояния загрязнения окружающей среды перед вводом в эксплуатацию РЦКДХ и могут быть использованы в практике регулирующего надзора в процессе его эксплуатации.

Ключевые слова: объект ядерного наследия, радиационно-гигиенический мониторинг, канцерогенный риск, техногенные радионуклиды, тяжелые металлы, здоровье населения, радиационная обстановка

Вклад авторов: Ю. Н. Зозуль - анализ и подготовка материалов исследования; С. М. Киселев, Т. Н. Лащенова - общее руководство, анализ материалов исследования; В. В. Шлыгин - проведение исследований радиационной обстановки, обработка данных; С. В. Ахромеев - проведение исследований методом спектрометрии, сбор информации; Т. И. Гимадова - проведение исследований методом интегральной ТЛ-дозиметрии; А. Н. Малахова - сбор информации, работа с ТЛ-дозиметрами; О. Б. Шашкова - проведение исследований методом атомно-абсорбционной спектрометрии; К. Ю. Оськина - проведение радиохимических исследований.

Соблюдение этических стандартов: все работы проведены с соблюдением мер радиационной безопасности и требований охраны труда.

$\bowtie$ Для корреспонденции: Юлия Николаевна Зозуль

ул. Живописная, д. 46, 123098, г. Москва; julnik@list.ru

Статья получена: 15.07.2021 Статья принята к печати: 11.08.2021 Опубликована онлайн: 27.08.2021

DOI: $10.47183 /$ mes.2021.022 
A modern technological platform for radioactive waste management is being constructed in the Russian Federation. As part of the implementation of this platform, regional facilities for the accumulated and new radioactive waste collection, reprocessing and detoxification are being established. The Regional center of conditioning and long-term storage of radioactive waste is constructed in Primorsky Krai since 2016. It is located in the vicinity of the Sysoev Bay industrial site of the Fokino branch of the Far Eastern Center for Radioactive Waste Management (Sysoev Bay site). According to the project, the production structure under construction is designed for reprocessing and detoxification of radioactive waste (RW) accumulated on the Sysoev Bay site and produced during the facilities' use and decommission. Regional status of the facility also entails collection and reprocessing of radioactive materials produced by other plants of the Far East region, i.e. plants engaged in decommissioning of Russian nuclear-powered vessels. Federal Medical Biological Agency of the Russian Federation is responsible for state sanitary and epidemiological supervision on the territories where the RW management is carried out [1].

The studied radiation-hazardous facility is located on the southeastern tip of the Dunay peninsula. There is a private sector of the Dunay urban-type settlement (Staryi Dunay settlement) in the area of the Sysoev Bay site, inhabited by permanent residents. Private sector is located along the railway down to Konushkov Bay and the state route, which had been used for transportation of containers with spent nuclear fuel to the facility. The local population lives in wooden and stone-built one-storey houses and practices subsistence farming. Water supply is decentralized; water for drinking and household needs is taken from underground sources (wells and boreholes). The inhabitants' diet includes local milk and vegetables grown in the garden. The population of the Staryi Dunay settlement is a critical group living in the area of potential impact excerted by the facility.

The territory of Regional center of conditioning and long-term storage of radioactive waste lies within the health protection zone (|HPZ) of the Sysoev Bay site in the vicinity of the production facility. The health physics situation on the territory of the newly built facility is conditioned by the production activities in the Sysoev Bay site. It has been working on managing RW, accumulated during military activities of the former coastal technical base for maintenance of nuclear submarines, for more than 20 years [2]. Currently, the stationary sources of artificial radionuclide emissions to atmosphere are the existing facilities of the Sysoev Bay site, liquid radioactive waste treatment facility, radiochemical laboratory and vehicle decontamination site (VD-8) [3]. According to Roshydromet, in 2017-2019 the content of artificial radionuclides in the atmospheric fall-out on the territory of Primorsky Krai reached the method detection limit. Maximum ambient air pollution $\left({ }^{137} \mathrm{Cs}-0.9 \times 10^{-7} \mathrm{~Bq} / \mathrm{m}^{3}\right.$; ${ }^{90} \mathrm{Sr}-2.7 \times 10^{-7} \mathrm{~Bq} / \mathrm{m}^{3}$ ) was many orders of magnitude below the permissible average annual acivity levels [4]. The average annual gamma dose rate in Primorsky Krai was $0.13 \mu \mathrm{Sv} / \mathrm{h}$ [5]. After the Regional center of conditioning and long-term storage of radioactive waste once completed, there would be another source of chemical and radioactive emissions, namely the exhaust vent of the technology block responsible for RW reprocessing and conditioning. The composition of collected RW included radioactive waste produced during the nuclear submarine disposal and RW rehabilitation. The dominant radionuclides were ${ }^{60} \mathrm{Co},{ }^{137} \mathrm{Cs}$, ${ }^{90} \mathrm{Sr}$.

Given the current situation and the planned intensification of activities related to RW management in the region, assessment of anthropogenic impact on the environment and population at the current stage of production activities in the Sysoev Bay site is an urgent task. The obtained data would be used as reference values for comparative environmental impact assessment in the further RW management production activities.

The study was aimed to perform environmental impact assessment of the territories in the vicinity of the Regional center of conditioning and long-term storage of radioactive waste in Primorsky Krai prior to the facility commissioning.

\section{METHODS}

Measurements, sampling, and sample analysis were performed following the conventional procedures approved by the certified Laboratory Centre at the Burnasyan Federal Medical Biophysical Center (Certificate No. RA.RU.21БY01).

Environmental radiation was assessed based on the gamma dose measurements with a Multirad-M detector (NTTS Amplituda; Russia) using the method of pedestrian gamma radiation survey.

Artificial radionuclide composition and specific activity were determined by gamma spectrometry with the use of gamma-ray spectrometer with germanium-based semiconductor detector (CANBERRA; USA) and radiometry with the use of UMF-200 radiometer (SPC "DOZA"; Russia), together with preliminary radiochemical separation.

Public dose assessment was performed for the situation of actual radiation exposure taking into account the regional background levels. Annual public dose was calculated as the sum of external radiation doses for the current year and the committed dose resulting from annual intake of radionuclides [4].

The average annual effective dose (hereinafter called AAED) of external exposure, both indoors and outdoors, was conservatively assessed based on the exposure of thermoluminescent dosimeter (TL-dosimeter) with lithium fluoride detector (DTG-4) in the tissue-equivalent cassette with a total thickness of $1 \mathrm{~g} / \mathrm{cm}^{2}[7]$.

Internal exposure doses due to oral intake of radionuclides with water and food were calculated based on the specific activity of artificial radionuclides [8].

Environmental heavy metal contamination was assessed by atomic absorption spectrometry using the Kvant 2 AT system (CORTEC; Russia). Of certain chemical elements, the paper reports data on heavy metal content for metals, which have been found in the samples in significant quantities.

Chemical contamination of soil was evaluated in accordance with the Guidelines [9] based on MPC (TPC) with the use of concentration factor $(\mathrm{Kc})$ relative to regional background value and cumulative pollution index (Zc) [10].

Heavy metal contamination of drinking water was assessed based on MPC stipulated in statutory documents [10].

Health risk was evaluated under the conservative scenario for a hypothetical person exposed to existing maximum levels throughout his/her life. Individual carcinogenic risk was calculated based on the exposure pathways for artificial radionuclides and heavy metals found in soil, drinking water and local food.

Health risk caused by radiation exposure was calculated based on AAED using the linear risk coefficient for malignant neoplasms for the overall population $\left(5.5 \times 10^{-2}\right)$ [11]. The risk, taking into account the exposure pathways, was evaluated in accordance with the Guidelines based on specific content of artificial radionuclides in soil, drinking water and food [12].

The risk caused by exposure to heavy metals was assessed under the permanent residence scenario based on the data 
on exposure and estimated carcinogenic potential values characteristic of additional individual carcinogenic risk or the risk of cancer depending on the carcinogen routes of intake [13].

Statistical processing of the results was performed using Microsoft Excel 2010 (Microsoft Corporation; USA). Median and its confidence limits $(\mathrm{CL})$ with $P=0.95$ were used as the central tendency indicators due to the measured values' inconsistency with normal or log-normal distribution [6]. According to the principle of conservatism, the values are reported taking into account the expanded uncertainty of measurements.

\section{RESULTS}

\section{Environmental impact assessment of the territory in the area of Regional center of conditioning and long-term storage of radioactive waste construction}

According to the results of assessment performed in the HPZ of the Sysoev Bay site in 2018-2020, the gamma dose rate in the area of the Regional center of conditioning and longterm storage of radioactive waste construction varies within the range of $0.03-0.23 \mu \mathrm{Sv} / \mathrm{h}$, and the median is $0.09 \mu \mathrm{Sv} / \mathrm{h}$, which is consistent with typical values registered in Primorsky Krai (0.09-0.18 $\mu \mathrm{Sv} / \mathrm{h})$, resulting from the regional background levels [5]. The dominant artificial radionuclides in the environment (soil, underground water) are ${ }^{137} \mathrm{Cs}$ and ${ }^{90} \mathrm{Sr}$ [14].

Specific activity of artificial radionuclides in soil is significantly below the requirements established for unlimited use of solid materials $A_{u U}$ [15]: the median content of ${ }^{137} \mathrm{Cs}$ is $17 \mathrm{~Bq} / \mathrm{kg}$ (maximum value is $63 \mathrm{~Bq} / \mathrm{kg}$ ), and the median content of ${ }^{90} \mathrm{Sr}$ is $3 \mathrm{~Bq} / \mathrm{kg}$ (maximum value is $4 \mathrm{~Bq} / \mathrm{kg}$ ). Excessive heavy metal concentrations with excessive quantities exceeding MPC for arsenic, lead, zinc, nickel, copper, vanadium and manganese have been detected (Table 1). Maximum values of cumulative pollution index (Zc) derived from regional backgrouns values do not exceed 16, which characterizes soil contamination level as "permissible".

\section{Environmental impact assessment of the residential area located in the vicinity of Regional center of conditioning and long-term storage of radioactive waste (Staryi Dunay settlement)}

Radiation situation on the territory of Staryi Dunay settlement characterized by gamma dose rate being within the range of
$0.05-0.21 \mu \mathrm{Sv} / \mathrm{h}$ (the median value is $0.10 \mu \mathrm{Sv} / \mathrm{h}$ ) corresponds to background levels registered in Shkotovsky District (the median value 0.10 is $\mu \mathrm{Sv} / \mathrm{h} ; \mathrm{Cl} 0.07-0.13 \mu \mathrm{Sv} / \mathrm{h}$ ) and typical values registered in Primorsky Krai $(0.09-0.18 \mu \mathrm{Sv} / \mathrm{h})$ [5]. The main dose-forming artificial radionuclides in the environment and food are ${ }^{137} \mathrm{Cs}$ and ${ }^{90} \mathrm{Sr}$.

Concentrations of ${ }^{137} \mathrm{Cs}$ and ${ }^{90} \mathrm{Sr}$ in soil of Staryi Dunay settlement correspond mostly to the regional background levels typical for Shkotovsky District (the median specific activity value for ${ }^{137} \mathrm{Cs}$ is $6 \mathrm{~Bq} / \mathrm{kg}$, and for ${ }^{90} \mathrm{Sr}$ it is $2 \mathrm{~Bq} / \mathrm{kg}$ ). Exceeding regional background levels for ${ }^{137} \mathrm{Cs}$ specific activity (median specific activity value for ${ }^{137} \mathrm{Cs}$ is $46 \mathrm{~Bq} / \mathrm{kg}$ ) elevated to the levels established for unlimited use of solid materials $\left(A_{u U}=100 \mathrm{~Bq} / \mathrm{kg}\right)$ are detected in soil samples taken from the roadsides. Based on artificial radionuclide specific activity (the median specific activity value for ${ }^{137} \mathrm{Cs}$ is $9 \mathrm{~Bq} / \mathrm{kg}$, and the value for ${ }^{90} \mathrm{Sr}$ is $2 \mathrm{~Bq} / \mathrm{kg}$ ), soils of home gardens meet the requirements established for unlimited use of solid materials [15].

Based on artificial radionuclide contents, drinking water from underground sources meets the requirements established for drinking water quality (Table 2) [4]. Specific activity of ${ }^{137} \mathrm{Cs}$ and ${ }^{90} \mathrm{Sr}$ in groundwater (wells, boreholes) is 3-4 orders of magnitude below the interventional level (IL).

Specific activity of artificial radionuclides in local food (milk, vegetables grown in the garden) is $2-4$ orders of magnitude below the permissible level (PL) established for food (Table 2) [16].

Assessment of external exposure of the population to artificial radionuclides based on the radionuclide contents in drinking water and local food has shown that exposure due to consumption of drinking water, milk and potato provides a key contribution (see Table 2). External exposure AAED for the population due to artificial radionuclides is $0.008 \mathrm{mSv}$ (0.0005 mSv due to ${ }^{137} \mathrm{Cs}$, and $0.007 \mathrm{mSv}$ due to ${ }^{90} \mathrm{Sr}$ ).

Assessment of external exposure of the population by dosimetry measuring the cumulative dose is based on the data obtained with TL-dosimeters installed outdoors and in residential buildings in Staryi Dunay settlement throughout the year. According to obtained results, AAED of external exposure measured outdoors does not exceed $1.70 \mathrm{mSv}$ with a median value of $1.03 \mathrm{mSv}$ (Table 3), which corresponds to background levels resulting from natural background radiation. External exposure of the population in the houses exceeds the outdoor values by $20 \%$. Based on the standard time spent

Table 1. Levels of heavy metals and arsenic in soils in the area of Regional center of conditioning and long-term storage of radioactive waste construction in 2017 and 2019

\begin{tabular}{|c|c|c|c|c|c|c|}
\hline \multirow{2}{*}{ Element } & \multirow{2}{*}{ Chemical hazard class } & \multicolumn{2}{|c|}{ Levels of heavy metals, mg/kg } & \multicolumn{3}{|c|}{ Assessment criteria, mg/kg } \\
\hline & & Median & Maximum & Regional background level ${ }^{\star}$ & $\mathrm{MPC} / \mathrm{TPC}^{\star \star}$ & $k_{\max }{ }^{* \star *}$ \\
\hline $\mathrm{Pb}$ & 1 & $66(38-180)$ & 180 & 62 & 65 & 260 \\
\hline $\mathrm{Cd}$ & 1 & $0,17(0,17-0,18)$ & 0,18 & 0,2 & 1 & - \\
\hline As & 1 & $8(8-9)$ & 9 & 12 & 5 & 15 \\
\hline $\mathrm{Zn}$ & 1 & $200(100-350)$ & 350 & 130 & 110 & - \\
\hline $\mathrm{Ni}$ & 2 & $46(27-100)$ & 100 & 35 & 40 & - \\
\hline $\mathrm{Cu}$ & 2 & $74(22-230)$ & 230 & 18 & 66 & - \\
\hline $\mathrm{Cr}$ & 2 & $130(110-170)$ & 170 & 110 & - & - \\
\hline V & 3 & $180(130-310)$ & 310 & 110 & 150 & 350 \\
\hline $\mathrm{Mn}$ & 3 & 2200 (770-2700) & 2700 & 1000 & 1500 & 15000 \\
\hline $\mathrm{Ba}$ & 3 & $890(570-1400)$ & 1400 & 700 & - & - \\
\hline $\mathrm{Sr}$ & 3 & $180(150-500)$ & 500 & 200 & - & - \\
\hline \multicolumn{2}{|r|}{ Zc } & $6(5-8)$ & 13 & - & - & - \\
\hline
\end{tabular}

Note: ${ }^{*}$ — results of original research; ${ }^{\star \star}$ — hygienic standards are provided for total forms for clayey and loamy soil with $\mathrm{pH}<5.5[10] ;{ }^{* \star \star}$ — maximum permissible content of the element based on one of four hazard indicators. 
Table 2. Internal exposure AAED in the population of Staryi Dunay settlement due to drinking water and local food intake

\begin{tabular}{|c|c|c|c|c|c|c|c|c|}
\hline \multirow{3}{*}{ Item } & \multicolumn{4}{|c|}{ Specific activity, Bq/L (kg) } & \multirow{3}{*}{$\begin{array}{l}\text { Consumpti-on, } \\
\text { kg/year }\end{array}$} & \multirow{2}{*}{\multicolumn{3}{|c|}{ Internal exposure AAED, mSv }} \\
\hline & \multicolumn{2}{|c|}{${ }^{137} \mathrm{Cs}$} & \multicolumn{2}{|c|}{${ }^{90} \mathrm{Sr}$} & & & & \\
\hline & $\begin{array}{l}\text { Staryi Dunay } \\
\text { settlement * }\end{array}$ & IL/ $\mathrm{PL}^{* *}$ & $\begin{array}{l}\text { Staryi Dunay } \\
\text { settlement * }\end{array}$ & IL/PL ** & & Due to ${ }^{137} \mathrm{Cs}$ & Due to ${ }^{90} \mathrm{Sr}$ & Total \\
\hline Ground drinking water & $\frac{0,005 \div 0,040}{0,012}$ & 11 & $\begin{array}{c}0,002 \div 0,143 \\
0,051\end{array}$ & 4,9 & 730 & $4 \times 10^{-5}$ & $9 \times 10^{-4}$ & $9 \times 10^{-4}$ \\
\hline Milk & $\frac{0,02 \div 0,62}{0,24}$ & 100 & $\begin{array}{c}0,03 \div 0,64 \\
0,24\end{array}$ & 25 & 136,5 & $3 \times 10^{-4}$ & $1 \times 10^{-3}$ & $2 \times 10^{-3}$ \\
\hline Potato & $\frac{0,02 \div 0,38}{0,11}$ & 80 & $\begin{array}{c}0,01 \div 7,3 \\
0,63\end{array}$ & 40 & 50,4 & $1 \times 10^{-4}$ & $4 \times 10^{-3}$ & $4 \times 10^{-3}$ \\
\hline Cucumbers & $\frac{0,01 \div 0,16}{0,06}$ & 60 & $\begin{array}{c}0,04 \div 0,19 \\
0,12\end{array}$ & 25 & 5,6 & $8 \times 10^{-6}$ & $8 \times 10^{-5}$ & $1 \times 10^{-4}$ \\
\hline Beets, carrots & $\frac{0,01 \div 0,06}{0,04}$ & 60 & $\begin{array}{c}0,04 \div 0,28 \\
0,12\end{array}$ & 25 & 10 & $9 \times 10^{-6}$ & $5 \times 10^{-4}$ & $5 \times 10^{-4}$ \\
\hline
\end{tabular}

Note: * numerator — range of variation, ${ }^{*}$ denominator — median; ${ }^{\star \star}$ drinking water — interventional level (IL) [4]; ${ }^{* *}$ food — permissible level (PL) [16].

by the population indoors (6,600 h) and outdoors (2,200 h), the median external exposure AAED value for the population, living close to the Regional center of conditioning and longterm storage of radioactive waste, is $1.18 \mathrm{mSv}$ (the regional background level is $1.15 \mathrm{mSv}$ ).

The total AAED for the population of Staryi Dunay settlement is $0.046 \mathrm{mSv}$ excluding regional background radiation, which is two orders of magnitude below the dose limits established by radiation safety standards [4]. External exposure, 0.030 mSv, makes a major contribution (over 65\%). Internal exposure AAED is $0.008 \mathrm{mSv}(0.007 \mathrm{mSv}$ due to food, $0.0009 \mathrm{mSv}$ due to drinking water).

Concentrations of metals and arsenic in soil and water on the territory of Staryi Dunay settlement are presented in Table 4.

Comparison of heavy metal contents in the soil of Staryi Dunay settlement with the regional background levels has revealed elevated levels of lead, copper, chromium, zinc and manganese. The highest MPC excess has been found for zinc, lead and copper. Elevated levels of zink that exceed MPC have been also registered for regional background levels, which characterize specific regional features of the territory. According to assessment of soil contamination by heavy metals based on the cumulative pollution index (Zc), the majority of soil samples (78\%) taken from the settlement are considered as having a "permissible" contamination level (Zc $<16)$. A total of $22 \%$ soil samples are considered as having a "moderately hazardous" contamination level $(16<$ Zc $<32)$ due to elevated copper, lead and zinc levels.

The results of groundwater contamination by heavy metals have shown that the quality of water in the wells and the majority of boreholes meets the requirements established for drinking water quality based on the concentrations of heavy metals and arsenic [10] (see Table 4).

The levels of elements from hazard classes 1 and 2 in drinking water do not exceed 0.1 MPC. MPC values exceeded for iron (hazard class 3 ) has been found in $40 \%$ of water samples taken from the wells. The levels of arsenic (hazard class 1), reaching or exceeding MPC, have been found in 30-40 m deep boreholes being the sources of private drinking water supply.

\section{DISCUSSION}

Health physics situation in the area of the Regional center of conditioning and long-term storage of radioactive waste built at the base of Sysoev Bay temporary storage facility has a number of features. Based on artificial radionuclide specific activity, soils in the area of the Regional center of conditioning and long-term storage of radioactive waste construction meet the requirements established for unlimited use of solid materials in accordance with OSPORB-99/2010. Gamma dose rate corresponds to the regional background level typical for the natural background radiation. Hygienic situation is compounded by the hazard class 1 element (lead, arsenic) levels exceeding MPC. Radiation situation in the residential area located in the vicinity of the Regional center of conditioning and long-term storage of radioactive waste corresponds to the regional background levels. The same situation is observed in the areas of RW storage facilities of the former coastal technical bases of the Northern Fleet in North-Western Russia [17]. Groundwater contamination with radioactive and chemical contaminants is an essential parameter for monitoring.

Analysis of carcinogenic risk for population resulting from exposure to radiation and chemical factors has been performed based on the field and laboratory research data.

Calculation of radiation risk for the population of Staryi Dunay settlement based on exposure pathways for artificial radionuclides contained in soil, drinking water and food, has shown that external exposure due to artificial radionuclides contained in soil provides a key contribution (Table 5). The risk of malignant neoplasms caused by radiation from artificial sources for the overall population, assessed based on the total AAED values [11], is $3 \times 10^{-6}$, which is considered the acceptable level.

Table 3. Average annual external exposure AAED in the population of Staryi Dunay settlement

\begin{tabular}{|l|c|c|c|c|}
\hline \multirow{2}{*}{ Territory } & \multirow{2}{*}{$\begin{array}{c}\text { Number of } \\
\text { measurements }\end{array}$} & Minimum & Maximum & Median (CL) \\
\cline { 3 - 5 } & & & & 1,5 \\
\hline Regional background level: & 19 & 0,46 & 2,07 & $1,00(0,50-1,48)$ \\
\hline - outdoors & 7 & 0,49 & & $1,20(0,57-1,25)$ \\
\hline - inside houses & 37 & & 1,7 & $1,03(0,55-1,51)$ \\
\hline Staryi Dunay settlement: & 18 & 0,49 & 2,13 & $1,23(0,67-1,70)$ \\
\hline - outdoors & 0,6 & & \\
\hline - inside houses & & & & \\
\hline
\end{tabular}


Table 4. Concentrations of heavy metals and arsenic in soil and underground water in the vicinity of Regional center of conditioning and long-term storage of radioactive waste

\begin{tabular}{|c|c|c|c|c|c|c|c|}
\hline \multirow{2}{*}{ Element } & \multirow{2}{*}{$\begin{array}{c}\text { Chemical hazard } \\
\text { class }\end{array}$} & \multicolumn{3}{|c|}{ Levels of heavy metals, $\mathrm{mg} / \mathrm{kg}(\mathrm{L})$} & \multicolumn{2}{|c|}{$\begin{array}{c}\text { Assessment criteria, } \\
\mathrm{mg} / \mathrm{kg}(\mathrm{L})\end{array}$} & \multirow{2}{*}{$K_{\mathrm{c}}$} \\
\hline & & Minimum & Maximum & Median & Regional background level & $\mathrm{MPC} / \mathrm{TPC}$ & \\
\hline \multicolumn{8}{|c|}{ Soil } \\
\hline $\mathrm{Pb}$ & 1 & 41 & 250 & $110(67-180)^{*}$ & 62 & 65 & 2 \\
\hline $\mathrm{Cd}$ & 1 & $<0,12$ & 0,51 & $0,23(0,12-0,51)^{\star}$ & 0,2 & 1 & 1 \\
\hline As & 1 & $<1$ & 3 & $2(1-3)^{\star}$ & 12 & 5 & $<1$ \\
\hline $\mathrm{Zn}$ & 1 & 100 & 820 & $215(140-460)^{\star}$ & 130 & 110 & 2 \\
\hline $\mathrm{Ni}$ & 2 & 22 & 47 & $42(34-45)^{\star}$ & 35 & 40 & 1 \\
\hline $\mathrm{Cu}$ & 2 & 19 & 260 & $67(41-130)^{\star}$ & 18 & 66 & 4 \\
\hline $\mathrm{Cr}$ & 2 & 55 & 300 & $155(130-160)^{*}$ & 110 & - & 1 \\
\hline V & 3 & 83 & 180 & $125(120-130)^{*}$ & 110 & 150 & 1 \\
\hline $\mathrm{Mn}$ & 3 & 670 & 2000 & $1300(1200-1400)^{\star}$ & 1000 & 1500 & 1 \\
\hline $\mathrm{Ba}$ & 3 & 510 & 1200 & $635(560-720)^{*}$ & 700 & - & 1 \\
\hline $\mathrm{Sr}$ & 3 & 130 & 310 & $160(140-220)^{*}$ & 200 & - & 1 \\
\hline & Zc & 2 & 21 & $6(3-9)^{\star}$ & - & - & - \\
\hline \multicolumn{8}{|c|}{ Groundwater (boreholes, wells) } \\
\hline As & 1 & $<0,005$ & 0,025 & $\begin{array}{c}<0,005 / 0,010^{* *} \\
<0,005\end{array}$ & $<0,005$ & 0,01 & - \\
\hline $\mathrm{Ba}$ & 2 & 0,01 & 0,04 & $\begin{array}{c}0,02 / 0,01^{* *} \\
0,02\end{array}$ & 0,03 & 0,7 & - \\
\hline $\mathrm{Cd}$ & 2 & $<0,0001$ & 0,0005 & $\begin{array}{c}0,0001 /<0,0001^{* *} \\
0,0001 "\end{array}$ & $<0,0001$ & 0,001 & - \\
\hline $\mathrm{Cr}$ & 2 & 0,001 & 0,005 & $\begin{array}{c}0,002 / 0,003^{* *} \\
0,002\end{array}$ & 0,001 & 0,05 & - \\
\hline $\mathrm{Pb}$ & 2 & $<0,001$ & 0,008 & $\begin{array}{c}0,001 / 0,007^{\star *} \\
0,001\end{array}$ & $<0,001$ & 0,1 & - \\
\hline $\mathrm{Sr}$ & 2 & 0,1 & 0,4 & $\begin{array}{c}0,19 /<0,10^{\star \star} \\
0,12\end{array}$ & 0,36 & 7 & - \\
\hline $\mathrm{Al}$ & 3 & 0,05 & 0,33 & $\begin{array}{c}0,05 / 0,05^{\star *} \\
0,06 \\
\end{array}$ & 0,12 & 0,2 & - \\
\hline $\mathrm{Cu}$ & 3 & $<0,01$ & 0,11 & $\begin{array}{c}0,01 / 0,02^{* *} \\
0,04\end{array}$ & $<0,01$ & 1 & - \\
\hline $\mathrm{Fe}$ & 3 & 0,01 & 1,36 & $\begin{array}{c}0,02 / 0,06^{\star *} \\
0,10\end{array}$ & 0,36 & 0,3 & - \\
\hline $\mathrm{Mn}$ & 3 & 0,01 & 0,64 & $\begin{array}{c}0,02 / 0,01^{\star *} \\
0,02 \\
\end{array}$ & 0,33 & 0,1 & - \\
\hline $\mathrm{Zn}$ & 3 & 0,01 & 1,5 & $\begin{array}{c}0,05 / 0,01^{* *} \\
0,01\end{array}$ & 0,01 & 1 & - \\
\hline
\end{tabular}

Note: * — median and its confidence limits; ${ }^{* *}$ numerator — median concentration in boreholes (70 m/30-40 m deep); ${ }^{* *}$ denominator — median concentration in wells.

Carcinogenic risk of exposure to chemicals due to heavy metal contamination of soil is considered acceptable $\left(1 \times 10^{-6}\right)$ (Table 6). The risk of using drinking water taken from wells and boreholes of $5 \times 10^{-6}$ meets the requirements established for acceptable risk to the population. The exception is drinking water from the 30-40 m deep boreholes, since the risk reaches $5 \times 10^{-4}$ due to presence of arsenic, which is is unacceptable to the overall population [13] and therefore requires further investigation. As mentioned above, the water sources for drinking and household water supply available in Staryi Dunay settlement are quite far from the Sysoev Bay temporary storage facility and are not exposed to the anthropogenic impact of the industrial site emissions and discharges. The presence of arsenic levels exceeding MPC in the water obtained from 30-40 m deep boreholes may be due to physical features of the water-bearing horizon in the studied area.

The study has shown that health risk caused by exposure to radiation for the population of Staryi Dunay settlement living in the vicinity of the Regional center of conditioning and long- term storage of radioactive waste is $4 \times 10^{-6}$. It does not exceed the risk caused by exposure to chemicals, which is $6 \times 10^{-6}$ (taking into account arsenic contained in water, the risk reaches $\left.5 \times 10^{-4}\right)$.

\section{CONCLUSIONS}

The paper presents the results of the complex environmental impact assessment of the Regional center of conditioning and long-term storage of radioactive waste, performed prior to to the Facility commissioning. It has been shown that radiation situation on the construction site and in adjacent residential area is characterized by background $\gamma$-dose rate and background concentrations of artificial radionuclides ${ }^{137} \mathrm{Cs}$ and ${ }^{90} \mathrm{Sr}$ in environmental media. At the same time, contamination with heavy metals and arsenic have been found in the ground of the production complex construction site and in the soil of home gardens located in the residential area. Qualitative composition of chemical contamination in the area of the Regional center 
Table 5. Individual radiation risk for the population of Staryi Dunay settlement

\begin{tabular}{|c|c|c|c|c|}
\hline \multirow{3}{*}{ Parameter } & \multirow{3}{*}{ Specific activity, Bq/kg (L) } & \multicolumn{3}{|c|}{ Individual radiation risk } \\
\hline & & \multicolumn{2}{|c|}{ Exposure } & \multirow{2}{*}{ Total } \\
\hline & & internal & external & \\
\hline Soil & & $3 \times 10^{-8}$ & $3 \times 10^{-6}$ & $3 \times 10^{-6}$ \\
\hline${ }^{137} \mathrm{Cs}$ & 89 & $3 \times 10^{-10}$ & $2 \times 10^{-6}$ & $2 \times 10^{-6}$ \\
\hline${ }^{90} \mathrm{Sr}$ & 160 & $3 \times 10^{-8}$ & $2 \times 10^{-6}$ & $2 \times 10^{-6}$ \\
\hline Water & & $4 \times 10^{-7}$ & - & $4 \times 10^{-7}$ \\
\hline${ }^{137} \mathrm{Cs}$ & 0,04 & $2 \times 10^{-8}$ & - & $2 \times 10^{-8}$ \\
\hline${ }^{90} \mathrm{Sr}$ & 0,14 & $4 \times 10^{-7}$ & - & $4 \times 10^{-7}$ \\
\hline Food & & $8 \times 10^{-7}$ & - & $8 \times 10^{-7}$ \\
\hline${ }^{137} \mathrm{Cs}$ & & $7 \times 10^{-8}$ & - & $7 \times 10^{-8}$ \\
\hline${ }^{90} \mathrm{Sr}$ & & $7 \times 10^{-7}$ & - & $7 \times 10^{-7}$ \\
\hline Total risk & & $1 \times 10^{-6}$ & $3 \times 10^{-6}$ & $4 \times 10^{-6}$ \\
\hline
\end{tabular}

Table 6. Individual carcinogenic risk caused by chemical pollution for the population of Staryi Dunay settlement

\begin{tabular}{|c|c|c|c|c|c|}
\hline \multirow{3}{*}{ Parameter } & \multirow{3}{*}{$\begin{array}{l}\text { Concentration, } \\
\mathrm{mg} / \mathrm{kg}(\mathrm{L})\end{array}$} & \multicolumn{4}{|c|}{ Individual carcinogenic risk } \\
\hline & & \multicolumn{3}{|c|}{ Intake } & \multirow{2}{*}{ Total } \\
\hline & & Ingestion & Inhalation & Dermal & \\
\hline \multicolumn{2}{|c|}{ Soil } & $4 \times 10^{-8}$ & $9 \times 10^{-7}$ & $3 \times 10^{-8}$ & $1 \times 10^{-6}$ \\
\hline $\mathrm{Cr}$ & 300 & - & $9 \times 10^{-7}$ & - & $9 \times 10^{-7}$ \\
\hline $\mathrm{Pb}$ & 250 & $4 \times 10^{-8}$ & $8 \times 10^{-10}$ & $3 \times 10^{-8}$ & $7 \times 10^{-8}$ \\
\hline $\mathrm{Ni}$ & 47 & - & $2 \times 10^{-9}$ & - & $3 \times 10^{-9}$ \\
\hline \multicolumn{2}{|c|}{ Drinking water* } & $4 \times 10^{-6}$ & - & $8 \times 10^{-7}$ & $5 \times 10^{-6}$ \\
\hline As & 0,025 & $5 \times 10^{-4}$ & - & $1 \times 10^{-5}$ & $5 \times 10^{-4}$ \\
\hline $\mathrm{Cd}$ & 0,00052 & $2 \times 10^{-6}$ & - & $6 \times 10^{-7}$ & $3 \times 10^{-6}$ \\
\hline $\mathrm{Pb}$ & 0,02 & $2 \times 10^{-6}$ & - & $2 \times 10^{-7}$ & $2 \times 10^{-6}$ \\
\hline \multicolumn{2}{|c|}{ Total carcinogenic risk* (water + soil) } & $4 \times 10^{-6}$ & $9 \times 10^{-7}$ & $8 \times 10^{-7}$ & $6 \times 10^{-6}$ \\
\hline
\end{tabular}

Note: * - calculated without taking into account the 30-40 m deep boreholes.

of conditioning and long-term storage of radioactive waste construction is characterized by high levels of arsenic, lead, zinc, nickel, copper, vanadium and manganese, and in the residential area it is characterized by high levels of zinc, lead and copper. In general, based on the results of soil contamination with heavy metals in the examined territories, soil has a "permissible" chemical contamination level. The excess of MPC has been found in a number of samples. The quality of drinking water in the residential area meets the requirements established for groundwater used in decentralized water supply systems, except for local boreholes, in which the arsenic levels exceeding MPC have been detected. The presence of arsenic in studied groundwater and soil may be due to specific regional features related to high levels of the element in environmental media. This fact requires clarification and further investigation. Comparative evaluation of carcinogenic risks caused by radiation exposure and chemical pollutants demonstrates comparable results: the approximate risk does not exceed $10^{-6}$ and therefore is considered negligible. The study results make it clear that hygienic situation determined by past and ongoing production activities in the facility (before commissioning of the Regional center of conditioning and long-term storage of radioactive waste does not pose any additional health risks caused by the impact of artificial radionuclides and heavy metals on the environment and the population living in the area of the Facility.

The results of complex environmental impact assessment, obtained prior to the Regional center of conditioning and longterm storage of radioactive waste commissioning, provide the basis for setting reference values of artificial radionuclide and heavy metal levels in environmental media and can be used for regulatory supervision aimed to ensure public safety during the facility operation.

\section{References}

1. Udalova AA, Geraskin SA, Aleksahin RM, Kiselev SM, Sovremennye podhody k ocenke radiacionnogo vozdejstvija na okruzhajushhuju sredu. Medicinskaja radiologija i radiacionnaja bezopasnost'. 2013; 58 (4): 23-33. Russian.

2. Shandala NK, Kiselev SM, Titov AV, Serjogin VA, Isaev DV, Ahromeev SV, i dr. Regulirujushhij nadzor i ocenka radiacionnoj obstanovki v rajonah razmeshhenija byvshih voennyh tehnicheskih baz. Gigiena i sanitarija. 2013; 92 (3): 15-19. Russian.

3. Otchet po jekologicheskoj bezopasnosti Dal'nevostochnogo centra po obrashheniju s radioaktivnymi othodami - filiala federal'nogo gosudarstvennogo unitarnogo predprijatija «Predprijatie po obrashheniju S radioaktivnymi othodami «RosRAO» (DVC «Dal'RAO» - filiala FGUP «RosRAO»). 2019 g. Dostupno po ssylke: https://www.rosatom.ru/upload/iblock/109/109b27982c8 cfd90a72224db545c17be.pdf. Russian.

4. Normy radiacionnoj bezopasnosti (NRB-99/2009) ot 02.07.2009. 
SanPiN 2.6.1.2523-09. Dostupno po ssylke: https://www.np-ciz. ru/userfiles/2_6_1_2523-09.pdf. Russian.

5. Radiacionnaja obstanovka na territorii Rossii i sopredel'nyh gosudarstv v $2019 \mathrm{~g}$. Ezhegodnik. Ministerstvo prirodnyh resursov i jekologii Rossijskoj Federacii. Obninsk, 2020; 343 s. Dostupno po ssylke: https://www.rpatyphoon.ru/upload/medialibrary/187/ ezhegodnik_ro_2019.pdf. Russian.

6. Statisticheskie metody. Statisticheskoe predstavlenie dannyh. Mediana. Opredelenie tochechnoj ocenki i doveritel'nyh intervalov. GOST R ISO 16269-7-2004. Dostupno po ssylke: https://docs. cntd.ru/document/1200035332. Russian.

7. Ionizirujushhee izluchenie, radiacionnaja bezopasnost'. Provedenie kompleksnogo jekspedicionnogo radiacionnogigienicheskogo obsledovanija naselennogo punkta dlja ocenki doz obluchenija naselenija. Metodicheskie rekomendacii. MR 2.6.1.0006-10. Dostupno po ssylke: https://docs.cntd.ru/ document/1200085909. Russian.

8. Ionizirujushhee izluchenie, radiacionnaja bezopasnost'. Kontrol' doz obluchenija naselenija, prozhivajushhego $v$ zone nabljudenija radiacionnogo ob"ekta, v uslovijah ego normal'no jekspluatacii i radiacionnoj avarii. Metodicheskie rekomendacii. MR 2.6.1.0063-12. Dostupno po ssylke: https://docs.cntd.ru/ document/1200095229. Russian.

9. Pochva, ochistka naselennyh mest, bytovye i promyshlennye othody, sanitarnaja ohrana pochvy. Gigienicheskaja ocenka kachestva pochvy naselennyh mest. Metodicheskie ukazanija. MU 2.1.7.730-99. Dostupno po ssylke: https://docs.cntd.ru/ document/1200003852. Russian.

10. Gigienicheskie normativy i trebovanija $k$ obespecheniju bezopasnosti i (ili) bezvrednosti dlja cheloveka faktorov sredy obitanija. SanPiN 1.2.3685-21. Dostupno po ssylke: https://docs. cntd.ru/document/573500115. Russian.

11. Ocenka radiacionnogo riska u naselenija za schet dlitel'nogo ravnomernogo tehnogennogo obluchenija $\mathrm{v}$ malyh dozah. Metodicheskie ukazanija. MU 2.1.10.3014-12. Dostupno po ssylke: https://docs.cntd.ru/document/1200095241. Russian.

12. Metodika ocenki radiacionnyh riskov na osnove dannyh monitoringa radiacionnoj obstanovki. Rekomendacii. R 52.18.7872013. Obninsk: FGBU «VNIIGMI-MCD», 2014; 116 s. Dostupno po ssylke: https://files.stroyinf.ru/Data2/1/4293754/4293754569. pdf. Russian.

13. Rukovodstvo po ocenke riska dlja zdorov'ja naselenija pri vozdejstvii himicheskih veshhestv, zagrjaznjajushhih okruzhajushhuju sredu. Rekomendacii. R 2.1.10.1920-04. Dostupno po ssylke: https:// docs.cntd.ru/document/1200037399. Russian.

14. Akhromeev SV, Kiselev SM, Titov AV, Seregin VA, Shlygin VV, Starinskaja RA. Issledovanie radiacionnoj obstanovki na ob"ektah jadernogo nasledija $\vee$ Dal'nevostochnom regione Rossii. ANRI. 2016; 1 (84): 65-71. Russian.

15. Osnovnye sanitarnye pravila obespechenija radiacionnoj bezopasnosti (OSPORB-99/2010). SP 2.6.1.2612-10. Dostupno po ssylke: https://orfi.ru/files/doc/uchcenter/ osporb_2612612-10.pdf.

16. Gigienicheskie trebovanija k bezopasnosti i pishhevoj cennosti pishhevyh produktov. SanPiN 2.3.21078-01. Dostupno po ssylke: https://docs.cntd.ru/document/901806306. Russian.

17. Shandala NK, Sneve MK, Titov AV, Smith GM, Novikova NYa, Romanov W, et al. Radiological criteria for the remediation of sites for spent fuel and radioactive waste storage in the Russian Northwest. Journal of Radiological Protection. 2008; 28: 479-97.

\section{Литература}

1. Удалова А. А., Гераськин С. А., Алексахин Р. М., Киселев С. М., Современные подходы к оценке радиационного воздействия на окружающую среду. Медицинская радиология и радиационная безопасность. 2013; 58 (4): 23-33.

2. Шандала Н. К., Киселёв С. М., Титов А. В., Серёгин В. А. Исаев Д. В., Ахромеев С. В. и др. Регулирующий надзор и оценка радиационной обстановки в районах размещения бывших военных технических баз. Гигиена и санитария. 2013; 92 (3): 15-19.

3. Отчет по экологической безопасности Дальневосточного центра по обращению с радиоактивными отходами филиала федерального государственного унитарного предприятия «Предприятие по обращению с радиоактивными отходами «РосРАО" (ДВЦ “ДальРАО» - филиала ФГУП «РосРАО»). 2019 г. Доступно по ссылке: https://www.rosatom. ru/upload/iblock/109/109b27982c8cfd90a72224db545c17be.pdf.

4. Нормы радиационной безопасности (НРБ-99/2009) от 02.07.2009. СанПиН 2.6.1.2523-09. Доступно по ссылке: https://www.np-ciz.ru/userfiles/2_6_1_2523-09.pdf.

5. Радиационная обстановка на территории России и сопредельных государств в 2019 г. Ежегодник. Министерство природных ресурсов и экологии Российской Федерации. Обнинск, 2020; 343 с. Доступно по ссылке: https://www. rpatyphoon.ru/upload/medialibrary/187/ezhegodnik_ro 2019.pdf.

6. Статистические методы. Статистическое представление данных. Медиана. Определение точечной оценки и доверительных интервалов. ГОСТ Р ИСО 16269-7-2004. Доступно по ссылке: https://docs.cntd.ru/document/1200035332.

7. Ионизирующее излучение, радиационная безопасность. Проведение комплексного экспедиционного радиационногигиенического обследования населенного пункта для оценки доз облучения населения. Методические рекомендации. MP 2.6.1.0006-10. Доступно по ссылке: https://docs.cntd.ru/ document/1200085909

8. Ионизирующее излучение, радиационная безопасность. Контроль доз облучения населения, проживающего в зоне наблюдения радиационного объекта, в условиях его нормальной эксплуатации и радиационной аварии.

Методические рекомендации. МР 2.6.1.0063-12. Доступно по ссылке: https://docs.cntd.ru/document/1200095229.

9. Почва, очистка населенных мест, бытовые и промышленные отходы, санитарная охрана почвы. Гигиеническая оценка качества почвы населенных мест. Методические указания. MУ 2.1.7.730-99. Доступно по ссылке: https://docs.cntd.ru/ document/1200003852.

10. Гигиенические нормативы и требования к обеспечению безопасности и (или) безвредности для человека факторов среды обитания. СанПиН 1.2.3685-21. Доступно по ссылке: https://docs.cntd.ru/document/573500115.

11. Оценка радиационного риска у населения за счет длительного равномерного техногенного облучения в малых дозах. Методические указания. МУ 2.1.10.3014-12. Доступно по ссылке: https://docs.cntd.ru/document/1200095241.

12. Методика оценки радиационных рисков на основе данных мониторинга радиационной обстановки. Рекомендации. Р 52.18.787-2013. Обнинск: ФГБУ «ВНИИГМИ-МЦД», 2014; 116 с. Доступно по ссылке: https://files.stroyinf.ru/ Data2/1/4293754/4293754569.pdf.

13. Руководство по оценке риска для здоровья населения при воздействии химических веществ, загрязняющих окружающую среду. Рекомендации. Р 2.1.10.1920-04. Доступно по ссылке: https://docs.cntd.ru/document/1200037399.

14. Ахромеев С. В., Киселев С. М., Титов А. В., Серегин В. А., Шлыгин В. В., Старинская Р. А. Исследование радиационной обстановки на объектах ядерного наследия в Дальневосточном регионе России. АНРИ. 2016; 1 (84): 65-71.

15. Основные санитарные правила обеспечения радиационной безопасности (ОСПОРБ-99/2010). СП 2.6.1.2612-10. Доступно по ссылке: https://orfi.ru/files/doc/uchcenter/osporb_2612612-10.pdf.

16. Гигиенические требования к безопасности и пищевой ценности пищевых продуктов. СанПиН 2.3.21078-01. Доступно по ссылке: https://docs.cntd.ru/document/901806306.

17. Shandala NK, Sneve MK, Titov AV, Smith GM, Novikova NYa, Romanov W, et al. Radiological criteria for the remediation of sites for spent fuel and radioactive waste storage in the Russian Northwest. Journal of Radiological Protection. 2008; 28: 479-97. 